ing members of that old Fourth District which at one time included very nearly the western half of the state.

The twenty-one judicial districts now in the state utilize seventy judges in conducting their courts. Two counties in the state cach comprise a whole judicial district.

Polk County with its six judges constitutes the Ninth Judicial District.

I.ee County with its two judges is alone designated as the Iirst Judicial District.

r.ee County has two county seats, one at Keokuk and one at fit. Madison. In the past it has been the custom to elect one judge from the northern half of the county and he generally has been a resident of $\mathrm{Ft}$. Madison. On the other hand one judge has always been a resident of Keokuk in the south half of the county. This has been changed and both judges now reside in Kcokuk.

Pottawattamic County is the other county in the state with two county seats, one at Council Bluft's and one at Aroca.

\title{
DES MOINES AGAIN NAVIGABLE
}

'The steamer, Coloncl Morgan, which has been permanently anchored at our wharf since last spring, was released from inprisonment yesterday morning, and took a trip down stream. Quite a number of passengers were aboard luxuriating in the prospect of a river excursion. A steamboat navigating the Des Moines in midwinter is an anomalous feature in Iowa.- The Iowa Citizen, Des Moines, February 6, 1858. (In the Newspitper Division of the Historical, Memorial and Art Department of Iowa.) 
Copyright of Annals of Iowa is the property of State of Iowa, by \& through the State Historical Society of Iowa and its content may not be copied or emailed to multiple sites or posted to a listserv without the copyright holder's express written permission. However, users may print, download, or email articles for individual use. 